\title{
Shifting assessment practices in the age of COVID-19
}

\begin{tabular}{|c|c|}
\hline $\begin{array}{l}\text { Authors: } \\
\text { Kim E. Dowde } \\
\text { Hennie J. Kriel }\end{array}$ & swell1,2 (1) \\
\hline $\begin{array}{l}\text { Affiliations: } \\
{ }^{1} \text { TTS Top Talen } \\
\text { Pretoria, Sout }\end{array}$ & $\begin{array}{l}\text { t Solutions, } \\
\text { Africa }\end{array}$ \\
\hline $\begin{array}{l}{ }^{2} \text { Department } \\
\text { Resource Man } \\
\text { Faculty of Eco } \\
\text { Management } \\
\text { University of } \\
\text { Pretoria, Sout }\end{array}$ & $\begin{array}{l}\text { f Human } \\
\text { agement, } \\
\text { nomic and } \\
\text { Sciences, } \\
\text { retoria, } \\
\text { Africa }\end{array}$ \\
\hline $\begin{array}{l}{ }^{3} \text { Department } \\
\text { and Organisati } \\
\text { Psychology, Fa } \\
\text { Economic and } \\
\text { Sciences, Univ } \\
\text { South Africa, P } \\
\text { South Africa }\end{array}$ & $\begin{array}{l}\text { f Industrial } \\
\text { ional } \\
\text { culty of } \\
\text { Management } \\
\text { ersity of } \\
\text { retoria, }\end{array}$ \\
\hline $\begin{array}{l}\text { Corresponding } \\
\text { Kim Dowdesw } \\
\text { kim.dowdeswe } \\
\text { com }\end{array}$ & $\begin{array}{l}\text { g author: } \\
\text { ell, } \\
\text { ell@tts-talent. }\end{array}$ \\
\hline $\begin{array}{l}\text { Dates: } \\
\text { Received: } 04 \mathrm{~J} \\
\text { Accepted: } 13 \\
\text { Published: } 28\end{array}$ & $\begin{array}{l}\text { an. } 2021 \\
\text { Apr. } 2021 \\
\text { May } 2021\end{array}$ \\
\hline $\begin{array}{l}\text { How to cite th } \\
\text { Dowdeswell, K } \\
\text { (2021). Shifting } \\
\text { practices in the } \\
\text { COVID-19. Afri } \\
\text { Psychological } \\
\text { 3(0), a50. https } \\
\text { org/10.4102/a. }\end{array}$ & $\begin{array}{l}\text { is article: } \\
\text { E., \& Kriek, H.J. } \\
\text { assessment } \\
\text { age of } \\
\text { can Journal of } \\
\text { Assessment, } \\
\text { s://doi. } \\
\text { jopa.v3i0.50 }\end{array}$ \\
\hline $\begin{array}{l}\text { Copyright: } \\
\text { (c 2021. The A } \\
\text { Licensee: AOSI } \\
\text { is licensed und } \\
\text { Creative Comm } \\
\text { Attribution Lic }\end{array}$ & $\begin{array}{l}\text { ISthors. } \\
\text { IS. This work } \\
\text { der the } \\
\text { nons } \\
\text { ense. }\end{array}$ \\
\hline Read online: & \\
\hline 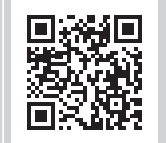 & $\begin{array}{l}\text { Scan this QR } \\
\text { code with your } \\
\text { smart phone or } \\
\text { mobile device } \\
\text { to read online. }\end{array}$ \\
\hline
\end{tabular}

The coronavirus disease 2019 (COVID-19) pandemic has had an unprecedented impact on the world of work, and we see a corresponding shift in the talent management and assessment spheres. This commentary reflects on the impact the pandemic has had on organisations' human resource (HR) practices in general and on assessment practices in particular. Informed by insights drawn from a series of in-depth interviews with representatives of organisations in South Africa and on the broader African continent, we consider recent trends in unproctored internet testing (UIT) and virtual or video interviewing technologies that appear central to how organisations have adapted their assessment practices in a COVID-19 world. We also consider the role of various assessment practices in retrenchment and restructuring applications. Finally, potential implications for organisations and their assessment practices when moving towards a postCOVID-19 world are discussed.

Keywords: talent assessment practices; COVID-19; unproctored internet testing; virtual interviewing; remote working; digitalisation; retrenchment.

Undoubtedly, the coronavirus disease 2019 (COVID-19) pandemic has had an unprecedented disruptive impact on the world of work, forcing fundamental changes to the way organisations function and how people work. Virtually overnight, organisations had to adapt their business strategies and operating models while workers found themselves either unable to work or working out how to work from home to limit the spread of the coronavirus. In this article, we reflect on the impact of the pandemic on organisations' human resource (HR) practices in general and on assessment practices $^{1}$ in particular and discuss implications for organisations on the way forward.

\section{Gaining insight into the impact of COVID-19 on organisations}

Our reflections are informed by observations arising from a series of in-depth interviews undertaken by the TTS Top Talent Solutions team with 41 key clients across a variety of industries. The semi-structured interviews sought to gain a thorough understanding of the pandemic's impact on clients' businesses and covered several key aspects of talent management and business processes in addition to understanding the impact the pandemic and lockdown had on organisations' hiring practices, talent assessment practices and adoption of new talent technologies (TTS Top Talent Solutions, 2020).

The interviews were conducted during July-September 2020 within the context of our client service provider relationships, with all participants providing their consent to be interviewed prior to our asking of their opinions on how the pandemic had influenced their organisations' use of assessments, amongst other related topics. Two-thirds of the participants were either executives, directors and heads of functions or held overall accountability for their organisation's assessment practices. Given the seniority of the majority of participants together with the range in participating organisations' size, industry and geographic location, we would argue that it lends credibility to the insights and opinions shared (see Table 1).

1.In this commentary, the term 'assessment practices' is used to encompass both psychological assessments, such as personality measures and cognitive ability tests, as well as 'other similar assessments', in line with Section 8 of South Africa's Employment Equity Act. This perspective acknowledges that other measures commonly used in employment contexts that are not necessarily psychological in nature, such as interviews and assessment centres, still need to have demonstrable evidence of the appropriateness of their use and that practitioners need to be mindful in how they utilise such measures in practice. 
TABLE 1: Description of participating organisations.

\begin{tabular}{llcc}
\hline Characteristic & Detail & Count & $\mathbf{\%}$ \\
\hline Participant role & Executive, director or head of functions & 16 & 39 \\
& Manager or assessment practices owner & 12 & 29 \\
& Consulting or industrial and organisational & 10 & 24 \\
& (IO) psychologist & 3 & 8 \\
& Talent specialist & 7 & 17 \\
Organisation size & Micro (1-6 staff) & 12 & 29 \\
& Small (<250 staff) & 1 & 2 \\
& Medium (<500 staff) & 3 & 7 \\
& Large (<1000 staff) & 18 & 44 \\
& Enterprise (1000 + staff) & 23 & 56 \\
Operating location & South Africa & 8 & 20 \\
& Africa & 10 & 24 \\
& International & 1 & 2 \\
Industry sector & Construction & 15 & 37 \\
& Finance and insurance & 1 & 2 \\
& Government & 2 & 5 \\
& Healthcare and social assistance & 1 & 2 \\
& Information & 1 & 2 \\
& Management of companies or enterprises & 3 & 7 \\
& Manufacturing & 1 & 2 \\
& Mining, quarrying and oil or gas extraction & 15 & 37 \\
\hline & Professional, scientific and technical services & 15 \\
& Wholesale trade & & 2 \\
\hline
\end{tabular}

Source: TTS Top Talent Solutions. (2020, December 08). COVID-19's impact on work and talent assessment practices. White Paper. Retrieved from https://www.tts-talent.com/blog/ whitepaper-the-impact-of-covid-19-on-work-and-talent-assessment-practices/

\section{The commercial and strategic business impact of COVID-19}

The commercial impact of the pandemic and ensuing national lockdowns around the world has been substantial. In South Africa in particular, gross domestic product (GDP) dropped by just over $16 \%$ between the first and second quarters of 2020, resulting in a negative annualised growth rate substantially worse than the contraction experienced during the 2009 global financial crisis (Statistics South Africa, 2020). In line with this economic downturn and GDP contraction, we found almost threequarters of participating client companies had experienced a negative to substantially negative commercial impact on their business. While only one participating organisation was undergoing a major restructuring specifically because of the COVID-19 crisis at the time of the interviews, one in five participating organisations had seen some staff retrenched and one in four anticipated retrenchments within the next 6 months.

The impact of the COVID-19 pandemic has been felt not only commercially and on client organisations' business models but also on their HR initiatives, with a substantial impact on organisations' hiring practices in particular. Unsurprisingly, given the pandemic's largely negative commercial impact, most participants noted a short-term reduction $(42 \%)$ or a complete freeze $(26 \%)$ on hiring. For the remaining participants noting either no impact or that hiring was continuing for critical roles only, the limitations on face-to-face contact imposed by lockdown regulations brought the opportunities offered by technology-enabled assessment practices into sharp focus. In the next section, we highlight two assessment practices that we believe became particularly salient during lockdown, supported by the observations of our client organisations.

\section{Leveraging technology in assessment practices in a COVID-19 world Unproctored internet testing}

Firstly, we believe the widespread use of unproctored Internet testing (UIT), enabled by technological advancements in assessment during the early 2000s, offered an avenue for many organisations to continue assessing people without risking face-to-face exposure. In an illustration of how Internet-delivered assessment has become the norm rather than the exception in the past decade (Foxcroft \& Roodt, 2018), Kantrowitz, Tuzinski and Raines (2018) reported the prevalence of online assessments in hiring applications to be $76 \%$ in a Middle East and African sample, and $84 \%$ in the global sample. In the South African context specifically during lockdown, more than half of our participating organisations indicated that the COVID-19 pandemic had no impact on how they were using assessments (presumably, already using online assessments prior to the COVID-19 crisis), while a further quarter reported either moving to online assessments (having not used them previously) or using more online assessments than previously. Participants also noted undertaking more structured validation interviews with candidates, given the increased usage of online unsupervised (but controlled) assessments, an increased focus on development rather than on hiring, and a change in criterion focus with specific consideration for individuals' suitability to remote working.

The temporary shuttering of workplaces and public facilities such as universities and libraries during the lockdown may give rise to renewed concerns about unequal candidate access to computer technology, which were prevalent during the early days of UIT adoption (Laher \& Cockcroft, 2013; Tippins et al., 2006). While such concerns are not unique to South Africa, they were and are particularly salient given the extreme inequality that persists in the country (World Bank, 2018). However, the increasing use of mobile-delivered assessments, again enabled by advancements in both technology and assessment science, could go a long way to mitigate this risk as tablets and smartphones are more affordable and ubiquitous than computers (Laher \& Cockcroft, 2013), and with South Africa's smartphone penetration reaching 91.2\% in 2019 (Independent Communications Authority of South Africa, 2020). Furthermore, recent studies have demonstrated the equivalence of mobile assessments both internationally (McClure Johnson, Capman, Siemsen, Martin, \& Boyce, 2019) and in South Africa (Meyer, Clifton, \& Dowdeswell, 2020), offering further support for their use in the local context.

\section{Virtual or video interviewing}

While many organisations placed a freeze on hiring in response to the commercial impact of the COVID-19 
pandemic, in our interviews with clients we noted a substantial uptake in the use of virtual or video interviewing. Prior to the COVID-19 crisis, virtual interviewing was used by less than one-third of participants; subsequently, this figure nearly doubled to almost $60 \%$ of participants, with a further one in five participants planning to adopt virtual interviewing at the time of the research. Interestingly, however, over two-thirds of participants reported utilising two-way or synchronous 'live' virtual interviews. This highlights that although several organisations have adopted virtual interviewing during the crisis, they are not necessarily tapping into the efficiency and speed benefits offered by asynchronous virtual interviewing technology platforms such as Hirevue (hirevue.com), Vidrecruiter (vidrecruiter. com), RecRight (www.recright.com) and Interview Rocket (interviewrocket.com). This is an important point that bears consideration as the light at the end of the tunnel (i.e. the recovery of economies and easing of financial constraints on organisations) draws closer: with job losses because of COVID-19 numbering in the millions around the world, it is reasonable to expect recruiters to be inundated with applications when organisations start opening up their hiring initiatives again. The utilisation of well-designed asynchronous virtual interviewing applications can support recruiters in dealing with the expected increase in applications in a fair and efficient manner, leveraging the demonstrated benefits of technology-assisted evaluation of candidates (Campion, Campion, Campion, \& Reider, 2016).

\section{Assessment practices in retrenchment and restructuring}

While leveraging technology enabled several organisations to successfully adapt their assessment practices to a COVID-19 world, the place of assessment practices in the retrenchment and restructuring necessitated by the economic crisis in many organisations is also an important discussion point. As a first consideration, because South African labour legislation requires personnel-related decisions to be based on job-inherent requirements, we asked affected organisations whether they had clear job or role specifications in place to assist with their retrenchment processes. The responses were of substantial concern: almost half of participating organisations affected by or anticipating retrenchments did not have clear job or role specifications in place to guide what assessment practices would be appropriate to inform decision-making. If retrenchment decisions are taken based on inaccurate job requirements, the organisation runs the risk not only of not retaining staff with the key knowledge, skills, abilities and other characteristics needed for successful recovery, but also opens themselves up to possible legal challenges.

A second key consideration informing the role of assessment practices in retrenchment and restructuring is the nature of the process: whether an organisation is purely reducing headcount or restructuring and redesigning roles. Where job requirements are not changing (i.e. in the case of downsizing), decisions should be made on the basis of employees' current job performance and other relevant criteria such as tenure and technical skills. In contrast, where job requirements are changing and new requirements are brought in, futureoriented assessment methods such as personality measures and cognitive ability tests can provide valuable insight into employees' potential to succeed in the new role (Bywater \& Thompson, 2005). This perspective is upheld by recent case law whereby the Labour Court found that psychometric tests may be used as assessment criteria to fill vacant posts during a retrenchment process (Pratten $v$ Afrizun KZN (Pty) Ltd, 2020), building on a previous Labour Appeal Court judgement that psychometric tests should not be used to select employees for retrenchments (South African Breweries v Louw, 2018).

\section{Organisations' perspectives of a post-COVID-19 world}

In September 2020, the World Bank reported anticipating that a full global economic recovery from the COVID-19 pandemic could take up to 5 years to achieve (Nagarajan, 2020), and exactly how the economic recovery will play out remains uncertain. When we asked our clients what they thought the talent management space would look like in a post-COVID-19 world, over $80 \%$ of participants stated that their talent functions would return to normal within the next year at least. Perhaps more aligned to the World Bank view, one in seven participants felt that the process could take up to 2 years and was more likely to require adapting to a new normal rather than returning to the old normal. For example, increased remote working and flexible hours was expected to be one of the top three anticipated changes, in line with Gartner's reported $82 \%$ of leaders intending to allow remote working at least some of the time and $47 \%$ of leaders supportive of remote working full-time (Gartner, 2020). Reasons given for this expectation include increased efficiencies and effectiveness leading to time and cost savings (for both organisations and staff), as well as broadening the reach of talent sourcing and applicant attraction beyond the organisation's immediate geographic locations or applicants' willingness to relocate.

The importance of the central role that technologyenabled assessment practices now hold in organisations is underscored by our clients' expectations that remote working will continue past the current crisis, and that ongoing support for digitalisation and digital transformation initiatives will continue to accelerate as it has done during the crisis. Surprisingly, then, given the disruptive impact of the COVID-19 pandemic on virtually all aspects of life, in our discussions with clients we found that $25 \%$ of participating organisations did not anticipate having to make any fundamental changes to how their organisations would operate in a post-COVID-19 world. While this view may be specific to a certain industry and not widespread across industries or organisational types, it may make preparing for a 'newly uncertain' future (Deloitte, 2020) more challenging. 


\section{Closing thoughts}

The COVID-19 pandemic has had wide-reaching implications for how organisations operate, organisational performance, and how talent and assessment practices are approached. A clear learning from 2020 is the central role played by technology in enabling operations to continue despite the ensuing national lockdowns. In this way, the pandemic has focused attention on how organisations orientate themselves to new ways of working and new technologies that enable this change. Despite some organisations intending to return to their old ways of working in the post-COVID-19 world, we believe that the pandemic has served as a flashpoint, emphasising the importance of utilising best-of-breed talent assessments and technologies to maintain and improve effectiveness, efficiency and candidate experience while insulating the organisation and its practices from future shocks as much as possible.

\section{Acknowledgements Competing interests}

The authors declared that they have no financial or personal relationships that may have inappropriately influenced them in writing this article.

\section{Authors' contributions}

H.J.K. was responsible for conceptualisation, project design and article review. K.E.D. was responsible for project design, analysis and article drafting and editing.

\section{Ethical considerations}

This article followed all ethical standards for research without direct contact with human or animal subjects.

\section{Funding information}

This research received no specific grant from any funding agency in the public, commercial or not-for-profit sectors.

\section{Data availability}

Data sharing is not applicable to this article as the views shared are the opinions of the authors.

\section{Disclaimer}

The views and opinions expressed in this article are those of the authors and do not necessarily reflect the official policy or position of any affiliated agency of the authors.

\section{References}

Bywater, J., \& Thompson, D. (2005). Personality questionnaires in a redundancy/ restructuring setting: What do we know now? Selection and Development Review, 21, 7-13.

Campion, M.C., Campion, M.A., Campion, E.D., \& Reider, M.H. (2016). Initial investigation into computer scoring of candidate essays for personnel selection.
Journal of Applied Psychology, 101(7), 958-975. https://doi.org/10.1037/ apl0000108

Deloitte. (2020). Recovering from COVID-19: Considering economic scenarios for resilient leaders. White paper. Retrieved from https://www2.deloitte.com/ content/dam/Deloitte/za/Documents/about-deloitte/za-Deloitte-Scenarios-forResilient-Leaders-April-2020-2.pdf

Foxcroft, C., \& Roodt, G. (2018). Introduction to psychological assessment in the South African context (5th edn.). Oxford University Press, Cape Town, South Africa.

Gartner. (2020, July 14). Gartner survey reveals $82 \%$ of company leaders plan to allow employees to work remotely some of the time. Press Release. Retrieved from https://www.gartner.com/en/newsroom/press-releases/2020-07-14-gartnersurvey-reveals-82-percent-of-company-leaders-plan-to-allow-employees-towork-remotely-some-of-the-time

Independent Communications Authority of South Africa. (2020). The state of the ICT sector report in South Africa, 2020. Retrieved from https://www.icasa.org.za/ uploads/files/State-of-the-ICT-Sector-Report-March-2020.pdf

Kantrowitz, T.M., Tuzinski, K.A., \& Raines, J.M. (2018). 2018 Global assessment trends report. White paper. Retrieved from https://www.shl.com/en/assessments/ trends/global-assessment-trends-report/

Laher, S., \& Cockcroft, K. (2013). Psychological assessment in South Africa: Research and applications 2000-2010. Wits University Press, Johannesburg, South Africa. https://doi.org/10.18772/22013015782

McClure Johnson, T.K., Capman, J.F., Siemsen, A., Martin, N.R., \& Boyce, A.S. (2019, April 04-06). Exploring equivalence and applicant reactions to a mobile cognitive assessment battery [Symposium]. 34th Annual Conference of the Society for Industrial and Organizational Psychology, National Harbor, MD.

Meyer, A., Clifton, S. \& Dowdeswell, K.E. (2020, December 01-03). Assessments on the go: Equivalence of smartphone vs. non-smartphone delivered cognitive test [Master tutorial]. 22nd Annual Conference of the Society for Industrial and Organisational Psychology of South Africa. Virtual.

Nagarajan, S. (2020, September 18). Full global recovery from Covid-19 may take 5 years, World Bank chief economist says. Business Insider. Retrieved from https:// years, World Bank chief economist says. Business Insider. Retrieved from https:// years-2020-9

Pratten v Afrizun KZN (Pty) Ltd (D439/15) [2020] ZALCD 9; (2020) 41 ILJ 2899 (LC) (17 April 2020). Retrieved from http://www.saflii.org/za/cases/ZALCD/2020/9. html

South African Breweries (Pty) Ltd v Louw (CA16/2016, C285/2014) [2017] ZALAC 63; [2018] 1 BLLR 26 (LAC); (2018) 39 ILJ 189 (LAC) (24 October 2017). Retrieved from http://www.saflii.org/za/cases/ZALAC/2017/63.html

Statistics South Africa. (2020, September 08). Steep slump in GDP as COVID-19 takes its toll on the economy. Retrieved from http://www.statssa.gov. $\mathrm{za} / \mathrm{p}=13601$

Tippins, N.T., Beaty, J., Drasgow, F., Gibson, W.M., Pearlman, K., Segall, D.O., \& Shepherd, W. (2006). Unproctored internet testing in employment settings. Personnel Psychology, 59(1), 189-225. https://doi.org/10.1111/j.1744-6570.2006.00909.x

TTS Top Talent Solutions. (2020, December 08). COVID-19's impact on work and talent assessment practices. White Paper. Retrieved from https://www.tts-talent.com/ $\mathrm{blog} /$ whitepaper-the-impact-of-covid-19-on-work-and-talent-assessmentpractices/

World Bank. (2018). Overcoming poverty and inequality in South Africa: An assessment of drivers, constraints and opportunities. Retrieved from http://documents. worldbank.org/curated/en/530481521735906534/pdf/124521-REV-OUO-SouthAfrica-Poverty-and-Inequality-Assessment-Report-2018-FINAL-WEB.pdf 